\title{
Seasonal Yield Response Factor for Red Bombay Onion (Allium cepa L.) Variety in Arba Minch, Ethiopia
}

\author{
Ligalem Agegn Asres
}

10.18805/ag.DF-387

\begin{abstract}
Background: For better water resources management in the areas of water shortage for crop production, deficit irrigation is very important. The understanding of the yield response factor to water deficit is crucial for efficient irrigation water management. Deficit irrigation for studying yield response factors is always practiced in the way of stressing the demand of the crops. The present study was done for the determination of the seasonal yield response factor of red Bombay onion variety under Arba Minch agro climate condition. Furthermore, it also examined the effect of furrow irrigation systems on the seasonal yield response factor.

Methods: The experiment was conducted from August to November 2019. The experiment had six treatments, which were the combination of two furrow irrigation systems and three irrigation levels. Data were collected for soil moisture before and after each irrigation and bulb yield. The seasonal yield response factors were determined through simple linear regressions using SPSS software. Result: When considering the furrow irrigation system as a factor, the seasonal yield response factor for alternate furrow irrigation system was 1.18 while for paired row furrow irrigation system was 1.07. This red Bombay variety of onion clearly shows more sensitive to water stress for alternative furrow irrigation systems than paired row furrow irrigation systems. Therefore, in the area of water shortage paired row furrow irrigation system is better than alternate furrow irrigation system. The seasonal yield response factor as a wall for red Bombay onion variety in Arba Minch agro-ecological condition was 1.12. Therefore, the red Bombay onion variety in Arba Minch agroclimate condition was sensitive to water stress.
\end{abstract}

Key words: Alternate furrow, Paired row furrow, Yield response factors.

\section{INTRODUCTION}

Water is essential for crop production improvement and any shortage has an impact on final yield production. Globally, irrigation in agriculture consumes about $70 \%$ of the available freshwater resources (FAO, 2016). To fulfill the food demand of the population, irrigation shall be expanded (Prajapat et al., 2020). Therefore, effective water utilization and water saving in irrigation are the most critical issues to be considered.

For better water resources management in the areas of water shortage for crop production, deficit irrigation is very important (Kannan and Anandhi, 2020). When climate change is observed where in increase in temperature and decrease in rainfall are observed (Kaur et al., 2021). Water will become more scarce. The increasing demand of irrigation water for food security and knowledge of crop yield response to water stress can improve the development of irrigation strategies for increasing yield productivity (Greaves and Wang, 2017; Joy et al., 2021; Roja et al., 2021; Wato, 2021). The understanding of yield response factor to water deficit is crucial for efficient irrigation water management (Kipkorir et al., 2002; Singh et al., 1987). Deficit irrigation for studying yield response factors, always practiced in the way of stressing the demand of the crops. Losing other factors, normal deficit irrigation is not productive. The effective planning and management of water for crop production requires precise knowledge of the irrigation system, climate conditions of the study area, soil condition, crop and its variety and levels of water management (Otarola et al., 2020; Kaboosi et al., 2012; Mila and Ali, 2016; Pejic et al., 2014). This means that the seasonal yield response
Faculty of Water Resources and Irrigation Engineering, Water Technology Institute, Arba Minch University, Arba Minch, Ethiopia.

Corresponding Author: Ligalem Agegn Asres, Faculty of Water Resources and Irrigation Engineering, Water Technology Institute, Arba Minch University, Arba Minch, Ethiopia.

Email: ligalemagegn@gmail.com

How to cite this article: Asres, L.A. (2022). Seasonal Yield Response Factor for Red Bombay Onion (Allium cepa L.) Variety in Arba Minch, Ethiopia. Agricultural Science Digest. DOI: 10.18805/ ag.DF-387.

Submitted: 28-07-2021 Accepted: 15-12-2021 Online: 12-01-2022

factor is affected by those factors. However, the listed factors can affect the seasonal yield response factor, but little work on the effect of irrigation system on seasonal yield response factors to identify the sensitivity levels of red Bombay onion crop variety are done.

Therefore, this paper was developed with the objective of determination of the seasonal yield response factor to water stress for Arba Minch climatic condition (local condition) of red Bombay onion variety. Furthermore, the effects of furrow irrigation systems on seasonal yield response factors were studied for improvement of crop water productivity. The selected variety would be identified whether sensitive to water stress or not in the local climate condition (Arba Minch agro-ecological condition). The effect of irrigation system on seasonal yield response factor was tested for further recommendations for the area of water 
scarcity. Investigators in the previous study were not considered the effect of irrigation systems on the seasonal yield response factor. The water consumption of the system is already different, but the yield may be the same or different. Therefore, the seasonal yield response factor was examined separately as well as all.

Onion crop is commonly grown for commercial and household consumption in Ethiopia specifically in Arba Minch. In nature, it is the raw material for making "Wot" (native word for Ethiopia). It grows between 500 and 2400 m.a.s.l., preferring an altitude between 700 and 1800 m.a.s.I., which are ideal for bulb production (Addis, 2020). There are a lot of different onion varieties that are produced in agricultural research center. The good potential of some of the onion varieties in Ethiopia are Adama red, red Bombay, Melkam and Nasic red (Addis, 2020). In line with this, the red Bombay onion variety is commonly cultivated by farmers in the Arba Minch area.

\section{MATERIALS AND METHODS}

The field experiment was conducted at Arba Minch University water technology institute demonstration farm in Gamo Zone, SNNPR National Regional State, Ethiopia. The period of this experiment was from August to November 2019. The study area is geographically located at an altitude of 1203 m.a.s.l, a latitude of $6^{\circ} 04^{\prime} \mathrm{N}$ and a longitude of $37^{\circ} 33^{\prime} \mathrm{E}$. The location of the study area is described in Fig 1.

Based on the data collected from the station, the mean monthly minimum and maximum air temperature in the area varies from $17.4^{\circ} \mathrm{C}$ to $30.6^{\circ} \mathrm{C}$, respectively. The average annual rainfall in the area is $750 \mathrm{~mm}$ (Gebreselassie et al., 2014). The rainfall is erratic and uneven in distribution. The average relative humidity varies from $39.4 \%$ (February) to $62.9 \%$ (May). The average annual daily sunshine duration ranged from $6.3 \mathrm{hrs}$ to $9.1 \mathrm{hrs}$. The agro-ecological zone of the study area was classified as dry low land. The behavior of dry low land includes an average altitude range from 5001400 m.a.s.l and the average annual rainfall below $900 \mathrm{~mm}$ (MOA, 2000).

\section{Method of irrigation system and experimental facilities}

The irrigation system was selected based on the degree of best irrigation water management. In the case of AFI (Alternate Furrow Irrigation), one of the two neighboring furrows is irrigated during each irrigation event and only one crop row is planted at the top of each of the furrows. In the PRFI (Paired Row Furrow Irrigation) system, crop planting is done at the top of the ridge in pairs (Micheal, 2007). Each crop row gets the water from side furrows and water is distributed to each furrow in each irrigation event.

The pre-experimental activities were nursery preparation, field preparation and soil sample collection and testing the samples in the laboratory and in situ. At the end, the bulb yield and the consumed water of the crop were recorded.

\section{Experimental treatments}

The experiment was conducted with two furrow irrigation systems that are alternate furrow irrigation $(\mathrm{AFI})$ and paired row furrow irrigation (PRFI) systems and three levels of irrigation as $100 \%, 75 \%$ and $50 \%$ ETc. Transplanting after 45 days of seedling of red Bombay onion variety was done in ridge and furrow system following the recommended agronomic practices.

The treatment plot size for the two systems was $1.6 \mathrm{~m}$ $\times 3 \mathrm{~m}$. The central rows for each treatment were considered as experimental rows for the collection of field data. The side rows were non-experimental (buffer row) to minimize the border effects. The plant to plant spacing in each row

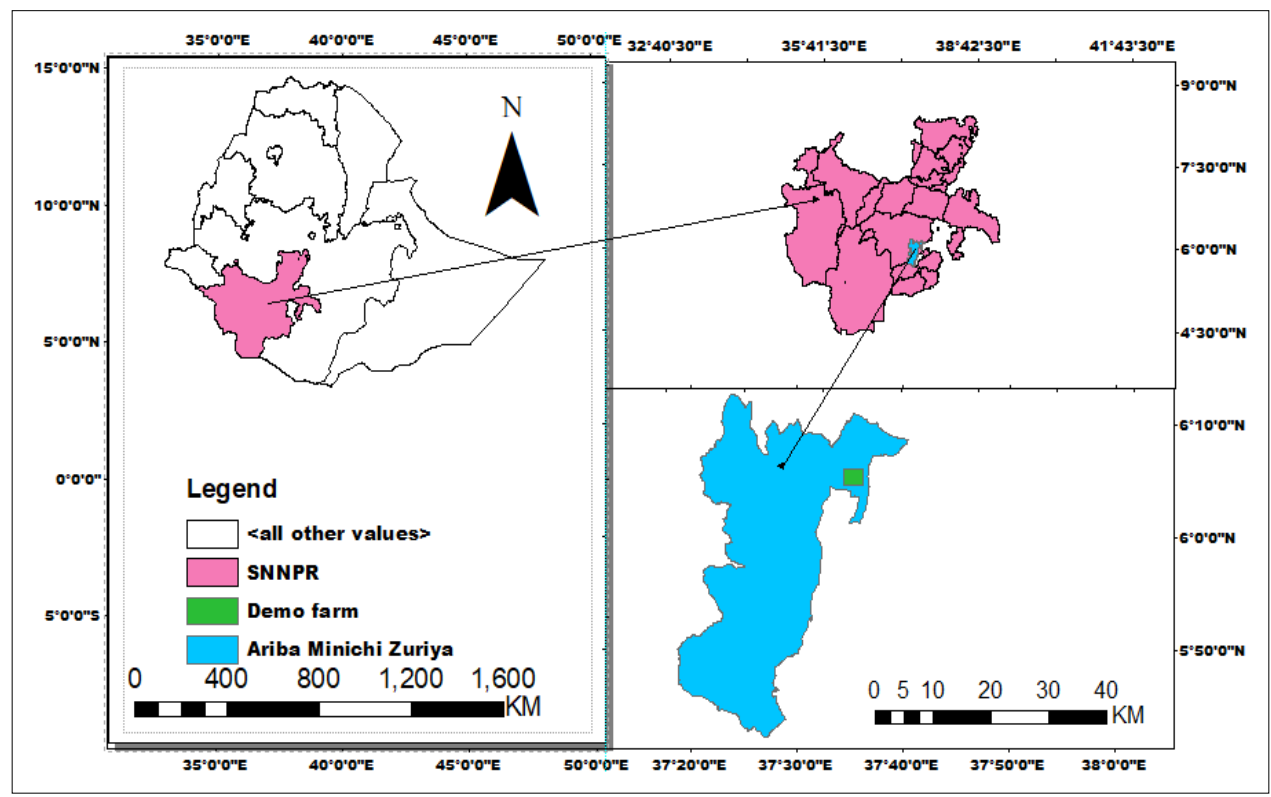

Fig 1: Location map of the study area. 
was $10 \mathrm{~cm}$ and has a plant density of 30 plants per row. There were 6 treatments; each of the treatments was replicated three times. The details of the treatments are given in Table1. The location of different plots was decided by a randomized complete block design (RCBD). The spacing between each treatment plot and each block was $1 \mathrm{~m}$ and $1.5 \mathrm{~m}$ respectively. The total experimental area was 240.7 $\mathrm{m}^{2}(16.6 \mathrm{~m} \times 14.5 \mathrm{~m})$.

\section{Soil physical properties of the study area}

The physical properties of the soil in the study area were determined in situ and in the laboratory. The physical properties of soil were texture, bulk density, field capacity and permanent wilting point. The soil texture for the soil of the experimental area was determined by Hydrometer analysis. The soil bulk density was determined by taking undisturbed soil samples and estimated using the standard formula. The field capacity was measured by ponding water at the soil surface to saturate the soil column, covering the soil surface with trace to prevent water evaporation from the soil surface and start the measurement of soil moisture content after 24 hours until a constant value was obtained. The permanent wilting point was considered at the soil moisture content of 15 atmospheric tensions.

\section{Crop water requirement estimation}

Onion crop water requirement was estimated from reference crop evapotranspiration (ETo) and crop coefficient (Kc) using Equation 1. The reference crop evapotranspiration (ETo) was estimated using CROPWAT 8 software based on the Penman-Monteith method.

$$
\mathrm{ETc}=\mathrm{Kc} \times \mathrm{ETo}
$$

The net irrigation requirement was estimated using Equation 2.

$$
\mathrm{I}=\mathrm{ETC}-\mathrm{Pe}-\mathrm{GW}-\mathrm{SM}
$$

Where;

$\mathrm{I}=$ net irrigation requirement $(\mathrm{mm})$,

$\mathrm{Pe}=$ effective rainfall $(\mathrm{mm})$,

$\mathrm{GW}=$ groundwater contribution $(\mathrm{mm})$.

$\mathrm{SM}=$ change in soil moisture $(\mathrm{mm})$.

The depth of the groundwater table during the crop season was more than $1.6 \mathrm{~m}$. Therefore, groundwater contribution (GW) was negligible. Effective rainfall within the specified schedule was estimated using the sum of daily crop evapotranspiration and the amount of daily rainfall. This empirical equation was described in Equation 3.

$\mathrm{Pe}=\sum \mathrm{ETC}$ if $\sum \mathrm{ETC}<$ rainfall or

$\mathrm{Pe}=$ rainfall if $\sum \mathrm{ETC}>$ rainfall

Where;

$\sum E T c$ = sum of crop evapotranspiration from previous irrigation to the time of rain $(\mathrm{mm})$.
Therefore, the gross irrigation depth was determined by dividing the net irrigation depth by the measured value of field application efficiency $(64.5 \%)$. This depth of water were supplied to each of the plots using a Siphon tube.

\section{Actual evapotranspiration}

The actual evapotranspiration during the crop growth period for each treatment was estimated from the measurement of soil moisture content. The soil moisture content was measured before and $24 \mathrm{hrs}$ after each irrigation at soil depth $0-30 \mathrm{~cm}$ and $30-60 \mathrm{~cm}$. The soil moisture measurements were made at the center row within the plant line (for AFI) and between rows or plant lines (for PRFI). The actual evapotranspiration (ETa) was estimated from the measured values of soil moisture content, effective rainfall and crop evapotranspiration using Equation 4.

Where;

$$
E T a=\left(\omega_{a i}-\omega_{b i}\right) A s_{i} \times Z r_{i}+P e+E T c_{1}
$$

$\mathrm{ETa}=$ Actual evapotranspiration between two irrigation $(\mathrm{mm})$. $\omega_{\mathrm{ai}}=$ Gravimetric soil moisture content after irrigation for $\mathrm{i}^{\text {th }}$ soil layer (fraction).

$\omega_{b i}=$ Gravimetric soil moisture content before next irrigation for $i^{\text {th }}$ soil layer (fraction).

$\mathrm{Zr}_{\mathrm{i}}=$ Crop root depth for $\mathrm{i}^{\text {th }}$ soil layer $(\mathrm{mm})$.

$A s_{i}=$ Apparent specific gravity for $i^{\text {th }}$ soil layer.

$\mathrm{Pe}=$ Effective rainfall between soil moisture measurement $(\mathrm{mm})$.

$\mathrm{ETC}_{1}=$ Crop evapotranspiration for one day after next irrigation (mm) until $24 \mathrm{hrs}$.

$\mathrm{i}=$ Soil layer.

\section{Seasonal yield response factor}

Many mathematical relationships have been developed to relate crop yield with water use (Kaboosi and Kaveh, 2012). The relationships are known as crop water production functions. In the present analysis, the crop water production functions as proposed by Doorenbos and Kassam (1979) were considered. This is mathematically expressed as Equation 5.

$$
\left(1-\frac{Y a}{Y m}\right)=K y\left(1-\frac{E T a}{E T m}\right)
$$

Where;

$\mathrm{Ky}=$ Seasonal yield response factor,

$\mathrm{Ya}=$ Aactual yield $\left(\mathrm{kg} \mathrm{ha}^{-1}\right)$ corresponding to $\mathrm{ETa}$,

$\mathrm{Ym}=$ Maximum crop yield under given management conditions that can be obtained when water is not limiting $\left(\mathrm{kg} \mathrm{ha}^{-1}\right)$ corresponding to ETm,

$\mathrm{ETa}=$ Actual evapotranspiration $(\mathrm{mm})$.

$\mathrm{ETm}=$ Maximum evapotranspiration obtained for non-limiting water conditions $(\mathrm{mm})$.

\begin{tabular}{|c|c|c|c|c|c|c|}
\hline \multirow{2}{*}{$\begin{array}{l}\text { Furrow irrigation system } \\
\text { Treatments }\end{array}$} & \multicolumn{3}{|c|}{ Alternate furrow irrigation (AFI) } & \multicolumn{3}{|c|}{ Paired row furrow irrigation (PRFI) } \\
\hline & AT1 & AT2 & AT3 & PT1 & PT2 & PT3 \\
\hline Levels of irrigation as ETc & $100 \%$ & $75 \%$ & $50 \%$ & $100 \%$ & $75 \%$ & $50 \%$ \\
\hline
\end{tabular}

The agronomic data such as bulb yield were collected during harvesting for each treatment. Similarly, soil moisture

Table 1: Treatment combination for different furrow irrigation systems and level of irrigation water. 
was collected before and after each irrigation throughout the season to measure the seasonal actual evapotranspiration. This collected data is important to estimate relative seasonal water use deficit and relative bulb yield decrease for the determination of the seasonal yield response factor of red Bombay onion variety. These values were used as an input for SPSS software to determine the value of seasonal yield response factors.

\section{Data analysis}

The linear regression equations for the determination of the yield response factors were analyzed using SPSS 20 statistical program.

\section{RESULTS AND DISCUSSION}

The soil texture observed from different layers of the field was silty clay. The average value of soil bulk density, field capacity, permanent wilting point and total available water were $1.26 \mathrm{~g} \mathrm{~cm}^{-3}, 0.36,0.201$ and 0.159 infractions. These values were very important physical properties for determination of crop evapotranspiration through the soil moisture measurement at each irrigation interval.

\section{Actual evapotranspiration and bulb yield}

The measured value of actual evapotranspiration and bulb yields for different treatments in AFI and PRFI were collected and presented in Tables 2 and 3 respectively.

Table 2: Actual evapotranspiration and bulb yield for alternative furrow irrigation system.

\begin{tabular}{lccc}
\hline Treatment & AT1 & AT2 & AT3 \\
\hline Actual evapotranspiration $(\mathrm{mm})$ & 399.46 & 332.95 & 275.82 \\
Bulb yield $\left(\mathrm{kg} \mathrm{ha}^{-1}\right)$ & 36277.8 & 28980.6 & 23077.8 \\
\hline
\end{tabular}

Table 3: Actual evapotranspiration and bulb yield for paired row furrow irrigation system.

\begin{tabular}{lccc}
\hline Treatment & PT4 & PT5 & PT6 \\
\hline Actual evapotranspiration $(\mathrm{mm})$ & 414.57 & 348.91 & 274.34 \\
Bulb yield $\left(\mathrm{kg} \mathrm{ha}^{-1}\right)$ & 37863 & 31659.3 & 24088.9 \\
\hline
\end{tabular}

Table 4: Estimated values of seasonal yield response factor for AFI system using SPSS software.

\begin{tabular}{lcc}
\hline Seasonal yield response factor & $\mathrm{R}^{2}$ & $\mathrm{~F}$ value for testing $\mathrm{R}^{2}$ \\
\hline 1.18 & 0.999 & 7596.41 \\
\hline
\end{tabular}

Table 5: Estimated seasonal yield response factor for PRFI system using SPSS software.

\begin{tabular}{lcc}
\hline Seasonal yield response factor & $R^{2}$ & $F$ value for testing $R^{2}$ \\
\hline 1.07 & 0.999 & 9211.91 \\
\hline
\end{tabular}

Table 6: Estimated seasonal yield response factor for all systems together using SPSS software.

\begin{tabular}{lcc}
\hline Seasonal yield response factor & $\mathrm{R}^{2}$ & $\mathrm{~F}$ value to for testing $\mathrm{R}^{2}$ \\
\hline 1.12 & 0.994 & 2282.621 \\
\hline
\end{tabular}

\section{Seasonal yield response factor for red Bombay onion variety}

As observed from Table 4 and Fig 2, the seasonal yield response factor for AFI for red Bombay onion variety in Arba Minch condition was 1.18. This indicates the crop is sensitive to water stress. According to Doorenbos and Kassam (1979), the $\mathrm{Ky}$ values greater than one $(\mathrm{Ky}>1)$, the crop is very sensitive to water stress, $\mathrm{Ky}<1$, the crop is more tolerant to water stress whereas $\mathrm{Ky}=1$, yield reduction is direct proportion to reduced water use.

As observed from Table 5 and Fig 3, the seasonal yield response factor for PRFI for red Bombay onion variety under Arba Minch agro-ecological condition was 1.07. This value was a little bit greater than one; means that a little bit sensitive to water stress.

The values observed from the two systems were different. The red Bombay onion variety was more sensitive for AFI than PRFI. The observed information shows that irrigation systems were the main factor that affects the yield response factor. The value of Ky under AFI was higher than the value observed under PRFI. The crop production system under PRFI was better than AFI was the reason why different sensitivity was observed in the same variety. However, the

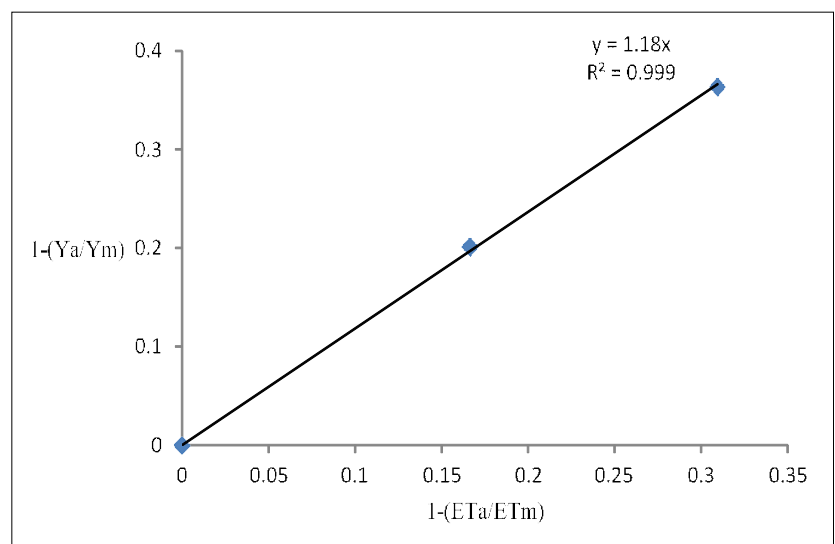

Fig 2: Seasonal yield response factor for AFI for red Bombay onion variety

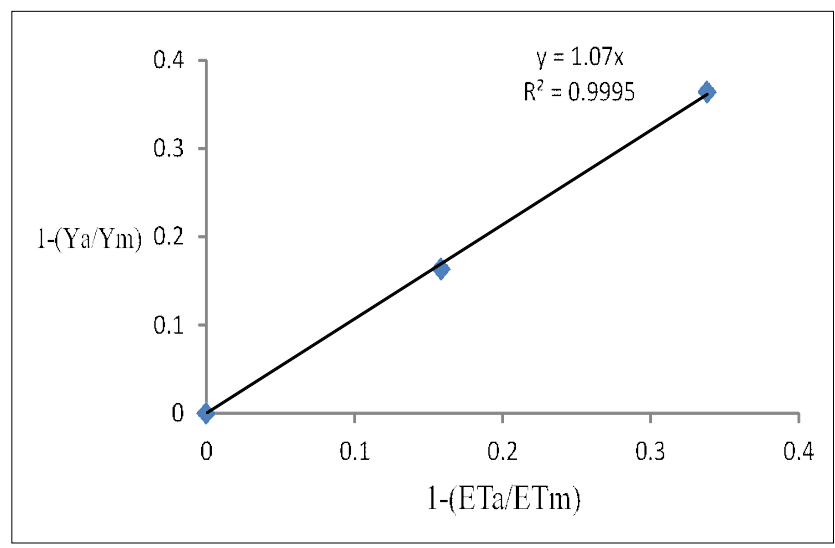

Fig 3: Seasonal yield response factor for PRFI for red Bombay onion variety. 


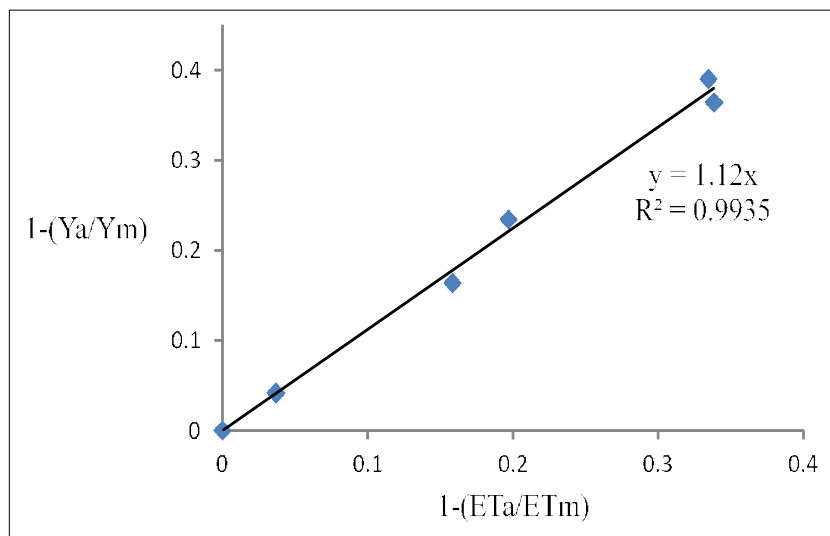

Fig 4: The seasonal yield response factor of Bombay red under Arba Minch agro climate.

Ky value observed under the PRFI was a little bit smaller than the values reported in Doorenbos and Kassam (1979) whereas greater for AFI. They reported that seasonal Ky for onion was 1.1. The difference of the value observed here may be the difference in variety, irrigation system, agroecological zone as well as soil types. However, in the area of water scarcity for red Bombay variety of onion PRFI systems was preferable than AFI for better maximize yield. When considering all furrow irrigation systems together, the estimated value of seasonal yield response factor of onion crop to water deficit for Arba Minch climatic condition was 1.12 (Table 6 and Fig 4). This result revealed that onion is more sensitive to water.

Similarly, the seasonal ky under combined conditions was more than one (the crop is more sensitive to water stress with more yield reduction). In line with this, Doorenbos and Kassam (1979) proposed a seasonal yield response factor (Ky) for onion crop equal to 1.1. Similarly, Kipkorir et al. (2002) recorded the seasonal yield response factor of onion was 1.28. On the other hand, Igbadun and Oiganji (2012) found that the seasonal yield response factor for onion under different treatments of no-mulch and mulched conditions by rice straw, white polyethylene and black polyethylene equal to $1.15,1.13,1.05$ and 1 respectively. In addition to this, Enchalew et al. (2016) also studied the seasonal yield response factor of onion for different water levels. He found $\mathrm{Ky}$ values for onion equal to $1.7,1.2,0.8,1$ and 1 for $90 \%$, $80 \%, 70 \%, 60 \%$ and $50 \%$ ETc level of irrigation respectively. The variation of the results was due to the system of irrigation, the variation of locations (climatic conditions) and a variety of onions (red Bombay). The previous authors conclude that the yield response factor was varied due to those listed factors (Kaboosi and Kaveh, 2012).

\section{CONCLUSION}

A yield response factor was a very important implication for different crops in water management practices. In line with this, it is important to identify the crops that are sensitive to water stress or not. The seasonal yield response factor for red Bombay onion variety under the factor of water stress and irrigation systems was considered in this study.

In this study, the seasonal yield response factor was estimated in the two furrow irrigation systems. The experimental treatments were developed with three levels of deficit irrigation (100\%, $75 \%$ and $50 \%$ ETc). Three treatments were designed for each system of furrow irrigation systems and replicated three times. The actual evapotranspiration for each treatment was estimated using the water balance equation. The bulb yields were collected during harvesting. The seasonal yield response factor was developed as a function of actual evapotranspiration and yield production using Doorenbos and Kassam (1979) in SPSS software.

The seasonal yield response factor for red Bombay onion variety for AFI system in Arba Minch agro climate condition was 1.18 whereas 1.07 for PRFI system. When considering the two systems as one, the seasonal yield response factor for red Bombay onion variety in Arba Minch agro-ecological condition was 1.12 .

To conclude this study, the seasonal yield response factor was affected by irrigation systems. In areas where irrigation water is scarce, paired row furrow irrigation system is better for red Bombay onion variety in Arba Minch agroecological conditions.

Here, the study was considered for one growing season to estimate the seasonal yield response factor for one variety of onions in one agro-ecological zone. Therefore, further studies considering those gaps are required.

\section{REFERENCES}

Addis, S. (2020). Onion (Allium cepa) varieties evaluation at Miyo District of Borana Lowland. Acta Scientific Agriculture. 4(3): 1-3.

Doorenbos, J. and Kassam, A.H. (1979). Yield Response to Water. FAO Irrigation and Drainage Paper No. 33. FAO, Rome Italy, 193.

Enchalew, B., Gebre, S.L., Rabo, M., Hindaye, B., Kedir, M. (2016). Effect of deficit irrigation on water productivity of onion (Allium cepa L.) under drip irrigation. Irrigation and Drainage System Engineering. 5: 1-4.

FAO. (2016). AQUASTAT Website. FAO's Information System on Water and Agriculture; Food and Agriculture Organization of the United Nations: Rome, Italy.

Gebreselassie, Y., Ayana, M. and Tadele, K. (2014). Field experimentation based simulation of yield response of maize crop to deficit irrigation using Aquacrop model, Arba Minch Ethiopia. African Journal of Agricultural Research. 10: 269-280.

Greaves, G.E. and Wang, Y.M. (2017). Yield response, water productivity and seasonal water production functions for maize under deficit irrigation water management in southern Taiwan. Plant Production Science. 20 (4): 353-365. DOI: 10.1080/ 1343943X.2017.1365613.

Igbadun, H.E. and Oiganji, E. (2012). Crop coefficients and yield response factors for onion (Allium cepa L.) under deficit irrigation and mulch practices in Samaru, Nigeria. African Journal of Agricultural Research. 7: 5137-5152. 
Joy, J.M.M., Mitra, B. and Roy, A.K.S. (2021). Growth and yield performances of wheat genotypes under restricted irrigation in eastern sub-Himalayan plains. Indian Journal of Agricultural Research. 55(4): 505-508. DOI: 10.18805/ IJARe.A-5545.

Kaboosi, K. and Kaveh, F. (2012). Sensitivity Analysis of FAO 33 Crop Water Production Function. Irrigation Science. 30: 89-100.

Kannan, N. and Anandhi, A. (2020). Water Management for Sustainable Food Production. Water. 12: 1-7. doi: 10.3390/w12030778.

Kaur, B., Singh, S.P. and Kingra, P.K. (2021). Simulating the impact of climate change on maize productivity in trans-gangetic plains using info crop model. Agricultural Science Digest. 41(1): 56-60. DOI: 10.18805/ag.D-5079.

Kipkorir, E.C., Raes, D. and Massawe, B. (2002). Seasonal water production functions and yield response factors for maize and onion in Perkerra, Kenya. Agricultural Water Management. 56: $229-240$.

Michael, A.M. (2007). Irrigation Theory and Practice ( $2^{\text {nd }}$ edition): India: Vikas Press: 1-727.

Mila, A.J., Ali, M.H. (2016). Irrigation-yield response factor of processing potato for different phenological growth stages. American Journal of Engineering Research. 5: 27-34.

MOA. (Ministry of Agriculture), (2000). Agroecological Zonations of Ethiopia. Addis Ababa, Ethiopia.
Otarola, M.K., Schutze, N., Holzapfel, E., Faundez, A.G., Mialyk, O., Rivera, D. (2020). Estimation of yield response factor for each growth stage under local conditions using AquaCrop-OS. Water. 12: 1-14. doi:10.3390/w12041080.

Pejic, B., Gajic, B., Bosnjak, D., Stricevic, R., Mackic, K. and Kresovic, B. (2014). Effects of water stress on water use and yield of onion. Bulgarian Journal of Agricultural Science. 20: 297-302.

Prajapat, A.L., Saxena, R., Choudhary, R.R. and Kumhar, M. (2020). Consumptive use, water use efficiency, moisture depletion pattern of wheat under semi-arid eastern plain zone of Rajasthan. Agricultural Science Digest. 40(4): 387-391.

Roja, M., Kumar, K.S., Ramulu, V. and Deepthi, Ch. (2021). Modeling and evaluation of aquacrop for maize (Zea mays L.) under full and deficit irrigation in semi-arid tropics. Indian Journal of Agricultural Research. 55(4): 428-433. DOI: $10.18805 /$ IJARe.A-5520.

Singh, P., Wolkewitz, H. and Kumar, R. (1987). Comparative performance of different crop water production functions for wheat. Irrigation Science. 8: 273-290.

Wato, T. (2021). Growth and yield performance of wheat (Triticum aestivum L.) to under water stress conditions. Agricultural Science Digest. 41(2): 301-306. DOI: 10.18805/ag.D-289. 